\title{
Recent Advances in Renewable Polymer Production from Lignin-Derived Aldehydes
}

\author{
Nahyeon Lee ${ }^{1,+}+\mathbb{D}$, Yong Tae Kim ${ }^{2,+}$ (D) and Jechan Lee ${ }^{1,3, *(\mathbb{D})}$ \\ 1 Department of Energy Systems Research, Ajou University, 206 Worldcup-ro, Suwon 16499, Korea; \\ skgus@ajou.ac.kr \\ 2 C1 Gas \& Carbon Convergent Research Center, Korea Research Institute of Chemical Technology, \\ 141 Gajeong-ro, Daejeon 34114, Korea; ytkim@krict.re.kr \\ 3 Department of Environmental and Safety Engineering, Ajou University, 206 Worldcup-ro, \\ Suwon 16499, Korea \\ * Correspondence: jlee83@ajou.ac.kr \\ + Designates the co-first authors who contributed equally to this work.
}

Citation: Lee, N.; Kim, Y.T.; Lee, J.

Recent Advances in Renewable Polymer Production from

Lignin-Derived Aldehydes. Polymers 2021, 13, 364. https://doi.org/

$10.3390 /$ polym 13030364

\section{Academic Editor:}

Nicolas Sbirrazzuoli

Received: 10 January 2021

Accepted: 21 January 2021

Published: 24 January 2021

Publisher's Note: MDPI stays neutral with regard to jurisdictional claims in published maps and institutional affiliations.

Copyright: (c) 2021 by the authors. Licensee MDPI, Basel, Switzerland. This article is an open access article distributed under the terms and conditions of the Creative Commons Attribution (CC BY) license (https:// creativecommons.org/licenses/by/ $4.0 /)$

\begin{abstract}
Lignin directly derived from lignocellulosic biomass has been named a promising source of platform chemicals for the production of bio-based polymers. This review discusses potentially relevant routes to produce renewable aromatic aldehydes (e.g., syringaldehyde and vanillin) from lignin feedstocks (pre-isolated lignin or lignocellulose) that are used to synthesize a range of biobased polymers. To do this, the processes to make aromatic aldehydes from lignin with their highest available yields are first presented. After that, the routes from such aldehydes to different polymers are explored. Challenges and perspectives of the production the lignin-derived renewable chemicals and polymers are also highlighted.
\end{abstract}

Keywords: aldehydes; biopolymer; biorefinery; lignin; lignocellulosic biomass; phenolics

\section{Introduction}

Lignocellulosic biomass has been regarded as the renewable alternative carbon that potentially replaces fossil fuel resources [1-5]. It consists mainly of cellulose, hemicellulose, and lignin [6]. Lignin is a heterogeneous aromatic biopolymer, which comprises 15-30\% of the weight of lignocellulosic biomass and an integral part of cell walls of terrestrial plants [7,8]. Lignin has aromatic structure; hence, it is considered a considerable renewable carbon source [9-12]. Nevertheless, the utilization of lignin has been limited to energy recovery. For example, most biorefinery processes degrade lignin, involving breakage of unstable ether bonds (e.g., $\beta-\mathrm{O}-4$ linkage) and $\mathrm{C}-\mathrm{C}$ bond formation of reactive intermediates via their condensation [13-16]. The resultant degraded lignin is usually incinerated for heat and power production because it is hard to be depolymerized $[17,18]$. In order to enhance sustainability and economics of biorefinery of using lignocellulosic biomass as a raw material, the effective utilization of lignin is crucial [19].

There have recently been efforts to search suitable renewable raw materials for polymer production. In particular, the development of bio-based polymers from lignin-derived monomers has gained great interest $[20,21]$. Within these contexts, this review provides upto-date summary and knowledge of bio-based polymers synthesized from lignin-derived aromatic aldehyde compounds. To this end, we first discuss a variety of methods to convert lignin into aromatic aldehydes (i.e., syringaldehyde and vanillin). Various routes from these substances to bio-based polymers are then outlined. At last, present challenges and prospects of the processes are discussed.

\section{Production of Aromatic Aldehydes from Lignin}

Aerobic oxidation of lignin under alkaline conditions selectively produces aromatic aldehydes such as syringaldehyde and vanillin [22]. Vanillin is commercially produced 
via alkaline aerobic oxidation of sulfonated lignin [23,24]. Alkaline oxidation of lignin has been extensively investigated mostly using condensed lignin feedstocks such as Kraft lignin [25-29] and sulfonated lignin [29-33]. For example, different research groups conducted studies into the effect of reaction parameters (e.g., temperature, $\mathrm{O}_{2}$ pressure, and $\mathrm{NaOH}$ concentration) on aerobic oxidation of Kraft lignin and sulfonated lignin [34-36]. Table 1 lists the results of alkaline aerobic oxidation of different lignins. Figure 1 illustrates reactions involved in aerobic oxidation of lignin to aromatic aldehydes (e.g., vanillin).
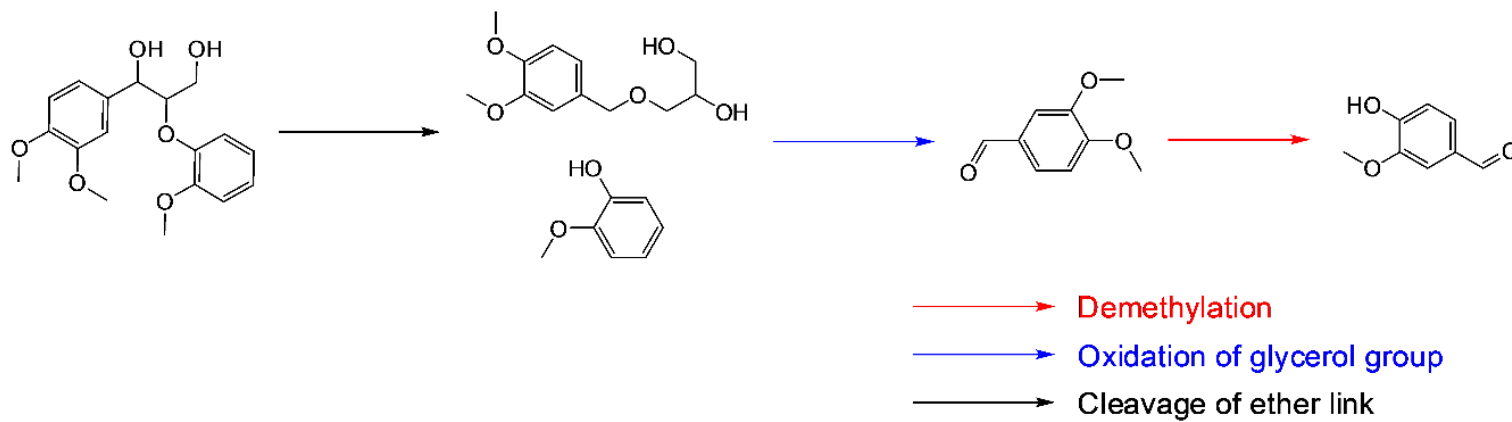

Figure 1. Potential reaction pathway for aerobic oxidation of lignin to vanillin via a series of reactions [37].

Earlier studies on alkaline aerobic lignin oxidation used lignins with highly modified structures (e.g., alkali-treated lignin, Kraft lignin, and lignosulfonates) [38-40] as the substrate. Such technical lignins have different structures and characteristics from native lignin because they change during delignification process, associated with delignification and biomass treatment and delignification methods. For example, Kraft lignin contains $1-3 \%$ sulfur, used to prepare resins, carbon fibers, and low-molecular-weight compounds. Organosolv lignin is sulfur-free and has many reactive sites, employed as additives to inks, paints, and coatings. Detailed comparison of characteristics of various technical lignin can be found in a recent review by Ekielski and Mishra [41].

In a recent study, a more native-like lignin (poplar sawdust containing $29.4 \mathrm{wt} . \%$ lignin) was used for the alkaline aerobic oxidation, as a surrogate substrate for an unmodified, highly reactive, and non-degraded lignin [42]. For this reaction, other than syringaldehyde and vanillin, syringic, $p$-hydroxybenzoic, and vanillic acids and acetosyringone were identified. During the oxidation of poplar lignin, the resultant syringaldehyde and vanillin were further oxidized to non-aromatic carboxylic acids. Vanillin was much less reactive for the formation of non-aromatic acids than syringaldehyde. High temperatures, high $\mathrm{NaOH}$ concentrations in the reactant, and short reaction times favored the production of syringaldehyde and vanillin. The reason why long reaction deteriorates the yield was the aromatic aldehydes degraded rapidly in the presence of oxygen. About $20 \mathrm{wt} . \%$ yield of syringaldehyde and vanillin was achieved with the poplar lignin at $175^{\circ} \mathrm{C}$ and $0.5 \mathrm{MPa} \mathrm{O}_{2}$ under $2 \mathrm{M} \mathrm{NaOH}$.

The work done by Schutyser et al. also investigated the effect of Cu-based catalysts $\left(\mathrm{CuSO}_{4}\right.$ or $\left.\mathrm{LaMn}_{0.8} \mathrm{Cu}_{0.2} \mathrm{O}_{3}\right)$ on alkaline aerobic oxidation of the poplar lignin [42]. These catalysts did not enhance the maximum aromatic aldehyde yield; however, they made the high yield could be obtained at a wider range of reaction conditions. The findings were somewhat contradictory to those of other studies that used modified lignins. This may be because the native-like lignin is reactive enough without catalyst compared to modified ones. The roles and mechanisms of the catalyst in the oxidation of the lignin contained in native biomass could not be explained, remaining as future studies.

Impurities contained in lignin feedstocks (e.g., inorganics and carbohydrates) may hinder the isolation of vanillin and syringaldehyde. Therefore, such impurities need to be removed from lignin (even technical lignin) prior to its oxidation in order to make uniformly fractionated lignin. The use of uniformly fractionated lignin would be beneficial to enhance the yield of vanillin and syringaldehyde. Various approaches to effectively 
isolate and recover vanillin and syringaldehyde from the reaction stream are found in the studies done by several groups [24,43,44].

Although many studies on the aromatic monomer production from lignin have carried out, there has been no study into economic feasibility of the aldehyde production from lignin yet. A recent paper, however, has reported technoeconomic feasibility of a ligninderived aromatic compound (e.g., catechol) [45]. The total cost investment of a plant which capacity is $2544 \mathrm{~kg}$ of feedstock per day was estimated to be approximately 4.9 million USD. The price of catechol production from lignin was calculated as 1100 USD per ton of catechol (a valorization ratio of 3.02). The estimation indicated that the lignin-derived catechol can be competitive in the market, while it was highly associated with assumptions on price of raw materials and sell price of products. A similar situation should be applied to a large-scale production of lignin-derived aromatic aldehydes. 
Table 1. Alkaline aerobic oxidation of different lignin feedstocks.

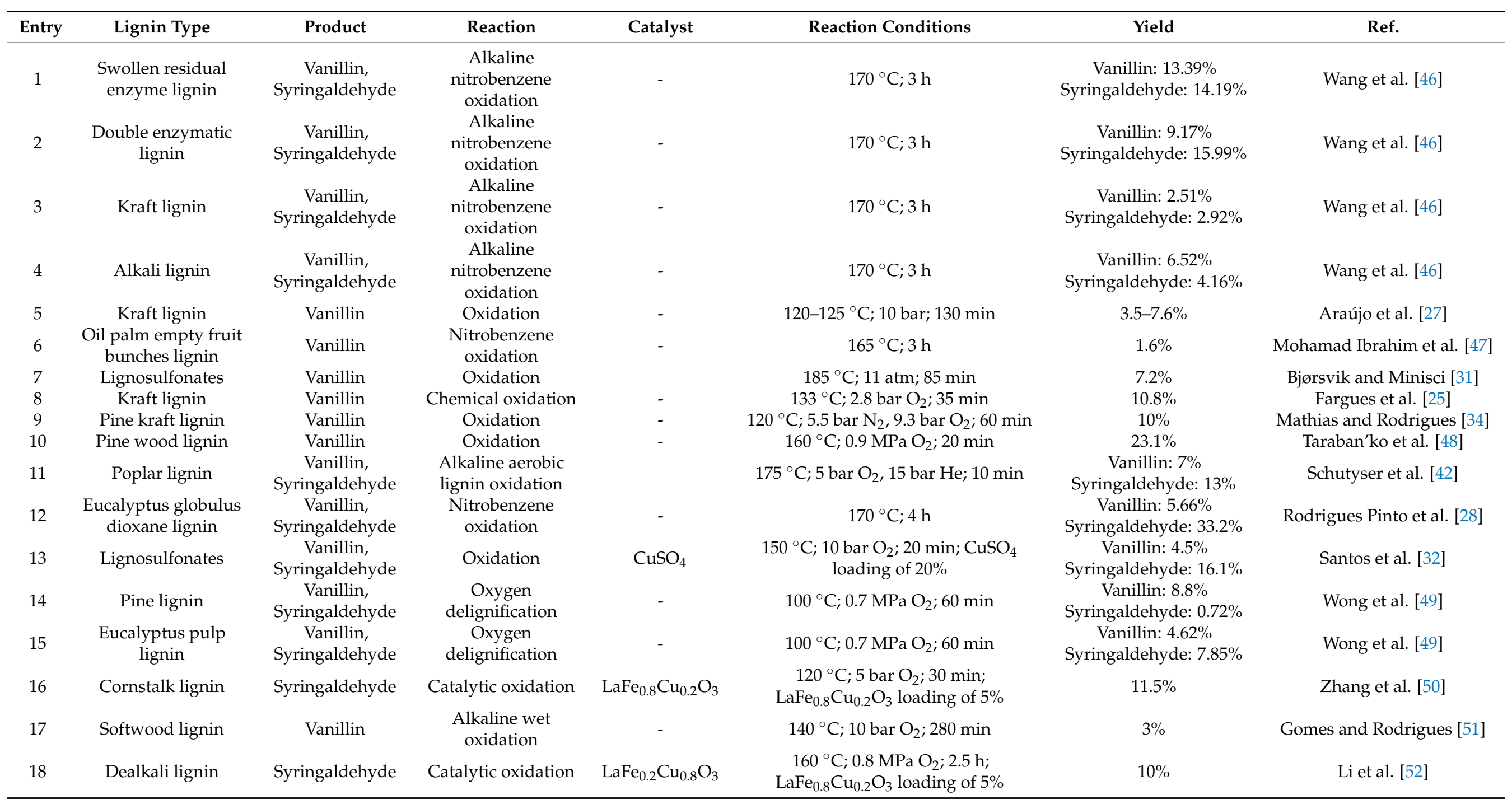


Table 1. Cont.

\begin{tabular}{|c|c|c|c|c|c|c|c|}
\hline Entry & Lignin Type & Product & Reaction & Catalyst & Reaction Conditions & Yield & Ref. \\
\hline 19 & Kraft lignin & Vanillin & $\begin{array}{l}\text { Alkaline wet } \\
\text { oxidation }\end{array}$ & CuMn (1:3) & $\begin{array}{c}150^{\circ} \mathrm{C} \text {; atmospheric pressure; } 60 \mathrm{~min} ; \\
\mathrm{CuMn} \text { loading of } 0.2 \%\end{array}$ & $6.7 \%$ & Jeon et al. [53] \\
\hline 20 & $\begin{array}{l}\text { Native softwood } \\
\text { lignin }\end{array}$ & Vanillin & Aerobic oxidation & - & $120^{\circ} \mathrm{C} ; 72 \mathrm{~h}$ & $21 \%$ & Maeda et al. [54] \\
\hline 21 & Kraft lignin & Vanillin & $\begin{array}{l}\text { Alkaline wet } \\
\text { oxidation }\end{array}$ & - & $140{ }^{\circ} \mathrm{C} ; 10$ bar $\mathrm{O}_{2} ; 2 \mathrm{~h}$ & $4.3 \%$ & Gomes and Rodrigues [55] \\
\hline 22 & $\begin{array}{l}\text { Lignin from } \\
\text { Kraft cooking liquor }\end{array}$ & Vanillin & $\begin{array}{l}\text { Alkaline } \\
\text { nitrobenzene } \\
\text { oxidation }\end{array}$ & - & $170^{\circ} \mathrm{C} ; 3 \mathrm{~h}$, & $3.9 \%$ & Gitaari et al. [56] \\
\hline 23 & Kraft lignin & Vanillin & Oxidation & - & $160{ }^{\circ} \mathrm{C} ; 1 \mathrm{MPa} \mathrm{O} 2 ; 1 \mathrm{~h}$ & $21.1 \%$ & Zhu et al. [57] \\
\hline 24 & Kraft lignin & Vanillin & Catalytic oxidation & $\mathrm{CuSO}_{4}$ & $140{ }^{\circ} \mathrm{C} ; 1 \mathrm{~h} ; \mathrm{CuSO}_{4}$ loading of $10 \%$ & $10.9 \%$ & Zhang et al. [58] \\
\hline 25 & Organosolv lignin & $\begin{array}{l}\text { Vanillin, } \\
\text { Syringaldehyde }\end{array}$ & Electro-oxidation & - & Room temperature; $1 \mathrm{~h}$ & $17.5 \%$ & Yan et al. [59] \\
\hline 26 & Kraft lignin & Vanillin & $\begin{array}{c}\text { Oxidative } \\
\text { depolymerization }\end{array}$ & - & $180-220^{\circ} \mathrm{C} ; 1-2$ atm $\mathrm{O}_{2} ; 1-2 \mathrm{~h}$ & $1.8-5.2 \%$ & Liu et al. [60] \\
\hline 27 & Eucalyptus lignin & $\begin{array}{c}\text { Vanillin, } \\
\text { Syringaldehyde }\end{array}$ & $\begin{array}{l}\text { Alkaline } \\
\text { nitrobenzene } \\
\text { oxidation }\end{array}$ & - & $170^{\circ} \mathrm{C} ; 4 \mathrm{~h}$ & $\begin{array}{c}\text { Vanillin: } 7.3 \% \\
\text { Syringaldehyde: } 29.3 \%\end{array}$ & Ninomiya et al. [61] \\
\hline
\end{tabular}




\section{Production of Polymers from the Lignin-Derived Aromatic Aldehydes}

\subsection{Production of Vanillin- and Syringaldehyde-Derived Polymers}

Lignin can be directly employed to produce various polymers such as polyesters, polyurethanes, and resins [62,63]. The polymers are synthesized directly from lignin via functionalization of hydroxyl groups in lignin structure, or lignin is utilized as blends, copolymers, and composites [64,65]. However, the direct use of lignin for the polymer production has several limitations. For instance, properties of the resultant polymers are highly dependent upon the composition and structure of lignin [66]; therefore, it is challenging to control the properties. In addition, lignin often comprises composites or blends as in minor amounts, and their major portions still originate from petroleum. Compared to lignin itself, lignin-derived monomers such as syringaldehyde and vanillin (discussed in Section 2) have relatively well-defined aromatic structure [65]. This aromatic structure gives important polymer properties like hydrophobicity, rigidity, and resistance to fire. In this section, it will be given an overview of methods employed to make different polymers from the lignin-derived syringaldehyde and vanillin. Figure 2 depicts various polymers that can originate from vanillin or syringaldehyde.

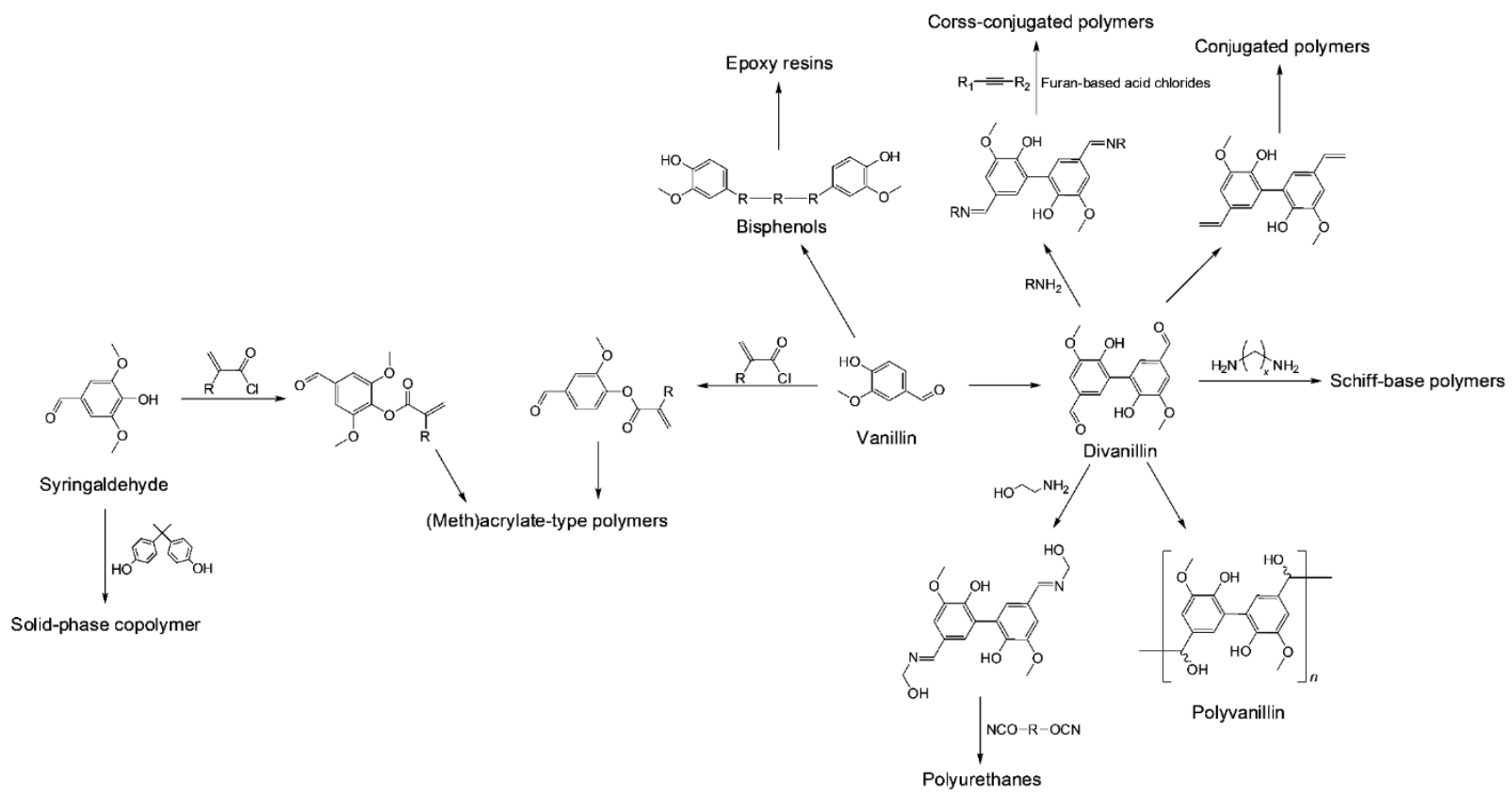

Figure 2. Various polymers that can originate from vanillin or syringaldehyde.

Among a wide range of aromatic monomers can be derived from lignin [67], only vanillin production is currently industrialized, which makes vanillin a particularly attractive monomer for polymer synthesis $[63,68]$. In earlier applications, vanillin is commonly functionalized to make epoxy resins [69-71] by adding a second alcohol [72] and used to make polymeric composite materials [73,74] and resins [75-77]. More recently, divanillin is used as a polymer precursor. Divanillin is readily made via enzymatic oxidative dimerization of vanillin on horseradish peroxidase (Armoracia rusticana) [78]. Alternatively, it can be produced oxidative coupling by using laccase [79-81], iron(III) chloride [82], and persulfate salts [83-85]. For instance, Fang et al. has very recently showed that sodium persulfate $\left(\mathrm{Na}_{2} \mathrm{~S}_{2} \mathrm{O}_{8}\right)$ is an effective persulfate salt for the synthesis of divanillin due to its high water solubility and inexpensiveness [85]. It could also be electrochemically synthesized [86]. No structural space and short segments in divanillin lead to minimizing rotational motion of its backbone, resulting in dynamic performance of polymeric networks $[81,87]$.

Divanillin has been applied to the synthesis of various polymers including polyvanillin [83,86], Schiff base polymers [88], epoxy thermosets [81,89,90], and lignin oligomers [91]. 
For example, reaction between divanillin and alkyl diamines in the presence of ethanol followed by reflux resulted in Schiff base polymers having the degree of polymerization ranging from 25 to 32 [88]. Divanillin could also be transformed to $\alpha, \omega$-dienes that were further converted into a conjugated polymer through acyclic diene metathesis [92]. Divanillin was employed as a chain extender to synthesize polyurethanes with a modification with ethanolamine [93]. Divanillin was able to electrochemically polymerized to polyvanillin considered a functionalized renewable polymer [86].

Bisphenols are precursors of a wide variety of polymers including polyesters [79], polycyanurates [72], polycarbonates [72], and epoxy resins [85,94] that are made through simple modifications of the structure of bisphenols. Two strategies have been available to make bisphenols from vanillin. First one involves coupling reactions between aromatic rings of two phenolic compounds through electrophilic condensation [95] or enzymatic dimerization [79]. Second one is to functionalize side chain of the phenolic species, involving coupling of two phenolics via a cross-linker [94] and the generation of stilbenes [72]. Song and co-workers enzymatically co-polymerized syringaldehyde with petro-derived bisphenol A using a peroxidase (Coprinus cinereus) [96].

Polymers synthesized by modifying side chain of vanillin or syringaldehyde have also been reported. Rostagno et al. prepared different polyvinyl aromatic acetals by the condensation of poly(vinyl alcohol) and lignin-derived aromatic aldehydes such as syringaldehyde and vanillin [97]. Polymeric vanillin prodrug-based nanoparticles were synthesized by Kwon et al. [98], which are potentially applied to drug delivery systems and antioxidant therapeutics. Liu et al. derived acrylamides from vanillin via a three-step process which could be polymerized through free radical polymerization [99]. The free radical polymerization could also be used to prepare acrylate polymers from syringaldehyde and vanillin [100].

There have been efforts to expand the application of renewable polymers derived from vanillin and syringaldehyde. For instance, Kakuchi and co-workers have recently exploited the Kabachnik-Fields reaction as a method to post-modify vanillin or syringaldehydederived polymer, considering that aldehydes are important reactants in multi-component reactions [101]. The Kabachnik-Fields multi-component reaction between phosphites, amines, and polymers derived from vanillin or syringaldehyde completely changed aldehyde functionalities of the polymers to $\alpha$-amino phosphonate functionalities.

An interesting use of renewable lignin-derived monomer was reported by Zhang et al. They synthesized polymeric porous microspheres from vanillin [102]. Vanillin first reacted with methacryloyl chloride, which made vanillin methacrylate. Suspension polymerization of the vanillin-derived monomer under aqueous phase resulted in microspheres with a >90 wt.\% yield. The microspheres had surface porosity by $\mathrm{N}_{2}$-bubbling and optimizing the co-solvent ratio. When the aldehyde functionalities of the microspheres reacted with glycine, the microspheres were chelated by Schiff base. The chelating microspheres showed a high performance of $\mathrm{Cu}^{2+}$ (as a heavy metal surrogate) adsorption (135 $\mathrm{mg} \mathrm{g}^{-1}$ ). Later on, the same researcher synthesized similar magnetic microspheres composed of polymethacrylate $/ \mathrm{Fe}_{3} \mathrm{O}_{4}$ nanoparticles [103]. The magnetic moiety allowed an easy separation of the material from liquid media after its use. The microspheres were effective at adsorbing $p$-anisidine, proving its suitability for enzyme immobilization.

\subsection{Properties of Vanillin- and Syringaldehyde-Derived Polymers}

Thermoset polymers are used in many applications including coatings, packaging, adhesives, composites, and electronics because of their high strength, high, modulus, and good resistance to heat and chemicals [104]. The properties of thermosets can readily be varied, dependent upon molecular weight, nature of the polymers, and adjustable cross-linking density [105]. Of various classes of thermosets, epoxy resins represent approximately $70 \%$ of thermoset market owing to their superior mechanical and adhesive properties and high thermal chemical resistance [106]. 
The lignin-derived vanillin and syringaldehyde (as discussed in Section 2) can be used to make epoxy thermosets. For example, Zhao and Abu-Omar made triphenylmethanetype polyphenols from syringaldehyde and vanillin [107]. The polyphenols were then reacted with or without linoleic acid (as a plasticizer), followed by epoxidation and curing to obtain a final form of the resin. The use of linoleic acid decreased glass transition temperature from 167 to $82{ }^{\circ} \mathrm{C}$ and storage modulus from 12.3 to $3.6 \mathrm{GPa}$ (entry 1 in Table 2).

Zhu and co-workers synthesized vanillin-based epoxy resins having flame retardant properties attributed to phosphorus functionalized by using $p$-phenylenediamine or 4,4diaminodiphenylmethane as coupling agent [94]. The procedure led to epoxy resins with thermal and mechanical properties that are comparable to commercial diglycidyl ether of bisphenol A (DGEBA) (entry 2 in Table 2).

Thermoplastic polymers are applied to manufacturing packaging, fibers, furniture, insulators, containers, medical equipment, automotive parts, et cetera. In addition to epoxy thermosets, thermoplastic polymers can be derived from vanillin and syringaldehyde. For instance, different methacrylate polymers with high glass-transition temperatures were derived from vanillin and syringaldehyde. Acrylate- and methacrylate-type monomers were first made, including vanillin acrylate, vanillin methacrylate, syringaldehyde acrylate, and syringaldehyde methacrylate [100]. Free radical polymerization of such monomers yielded their corresponding polymers. The polymers $\left(95-180^{\circ} \mathrm{C}\right)$ had a lot higher glass transition temperature than poly (methyl methacrylate) (PMMA), polystyrene (PS), and polylactic acid (PLA) $\left(48-110^{\circ} \mathrm{C}\right.$ ) (entry 4 in Table 2). They also had higher initial degradation temperature ranging from 300 to $320^{\circ} \mathrm{C}$ than PMMA $\left(280^{\circ} \mathrm{C}\right)$ and PLA $\left(296^{\circ} \mathrm{C}\right)$. Kim group used a dimerized vanillin to partially replace traditionally used chain extender (e.g., 1,4-butanediol) to make polyurethanes [93]. The resultant polymeric materials that containing divanillin-ethanol amine conjugate had enhanced Young's modulus (8.0-9.7 MPa) and strain $(644.8-770.9 \%)$ than those of typical polyurethane (7.5 MPa and $522.6 \%$, respectively) (entry 9 in Table 2).

Kayser et al. reported a cross-conjugated pyrrole-based fluorescent polymer comprising biomass-derived monomers such as vanillin and furan-based acid chlorides for the first time [108]. Multi-component polymerization substituted by catechyls and mediated by phosphonites was used to make the cross-conjugated polymer using light alkenes (or alkynes) and diacid chlorides. Investigation into the polymer's optical properties (e.g., fluorescence and UV-vis absorbance) proved that the polymer is blue-emitting, and the emission can be modulated by modifying its structure. The authors of this study stated that the polymer is potentially applied to produce polymer-based light emitting diode. Properties of more vanillin- and syringaldehyde-derived polymers are also available in Table 2. 
Table 2. Thermomechanical properties of vanillin- and syringaldehyde-derived polymers.

\begin{tabular}{|c|c|c|c|c|c|c|c|}
\hline Entry & Monomers & $\begin{array}{l}\text { Polymerization } \\
\text { Method }\end{array}$ & Final Polymer & $\begin{array}{l}\text { Glass Transition } \\
\text { Temperature }\left({ }^{\circ} \mathrm{C}\right)\end{array}$ & Degradation Temperature $\left({ }^{\circ} \mathrm{C}\right)$ & Other Properties & Ref. \\
\hline 1 & $\begin{array}{l}\text { Vanillin, } \\
\text { syringaldehyde }\end{array}$ & $\begin{array}{l}\text { Epoxidation; curing at } \\
80^{\circ} \mathrm{C} \text { for } 8 \mathrm{~h}\end{array}$ & Epoxy resin & $82-167^{a}$ & $T_{5 \%}=220-269^{b}$ & - & Zhao et al. [107] \\
\hline 2 & Vanillin & $\begin{array}{l}\text { Epoxidation; curing at } \\
160^{\circ} \mathrm{C} \text { for } 2 \mathrm{~h}\end{array}$ & Epoxy resin & $166-214^{\mathrm{c}}$ & $T_{5 \%}=286-356^{\mathrm{d}}$ & - & Wang et al. [94] \\
\hline 3 & $\begin{array}{l}\text { Vanillin } \\
\text { methacrylate }\end{array}$ & $\begin{array}{c}\text { Suspension } \\
\text { polymerization; curing } \\
\text { at } 65^{\circ} \mathrm{C} \text { for } 6 \mathrm{~h}\end{array}$ & $\begin{array}{l}\text { Polyvanillin } \\
\text { methacrylate }\end{array}$ & $102^{\mathrm{c}}$ & Degradation $T$ range $=250-480^{b}$ & - & Zhang et al. [102] \\
\hline 5 & Vanillin & $\begin{array}{l}\text { Electrochemical } \\
\text { reductive } \\
\text { polymerization }\end{array}$ & Polyvanillin & - & $T_{50 \%}=440^{d}$ & $\begin{array}{c}M_{\mathrm{n}}=9850-11,784 \mathrm{~g} \mathrm{~mol}^{-1} \\
Đ=1.42-1.58\end{array}$ & Amarasekara et al. [86] \\
\hline 6 & Vanillin & $\begin{array}{l}\text { Reversible addition- } \\
\text { fragmentation } \\
\text { chain-transfer (RAFT) } \\
\text { polymerization }\end{array}$ & $\begin{array}{l}\text { Methacrylate-type } \\
\text { polymers }\end{array}$ & $111-139$ & $T_{\max }=281-327$ & $\begin{array}{c}M_{\mathrm{n}}=15,000-41,000 \mathrm{~g} \mathrm{~mol}^{-1} \\
Đ=1.12-1.39\end{array}$ & Holmberg et al. [109] \\
\hline 8 & $\begin{array}{l}\text { Vanillin-derived } \\
\text { bis-benzoxazine } \\
\text { monomer }\end{array}$ & $\begin{array}{l}\text { Ring opening } \\
\text { polymerization }\end{array}$ & Poly(bisbenzoxazine) & $202-255^{\mathrm{e}}$ & Degradation $T$ range $=220-450^{b}$ & 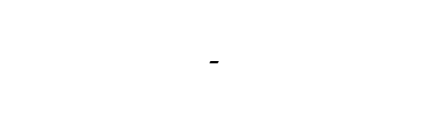 & Sini et al. [111] \\
\hline 9 & Vanillin & - & $\begin{array}{l}\text { Divanillin-ethanol } \\
\text { amine } \\
\text { conjugate-based } \\
\text { polyurethane }\end{array}$ & -68.1 to $-67.2^{c}$ & $T_{5 \%}=329.6-341.5^{b}$ & - & Gang et al. [93] \\
\hline 10 & $\begin{array}{l}\text { Vanillin, } \\
\text { syringaldehyde, } \\
\text { etc. }\end{array}$ & - & Polyvinyl acetals & $114-157$ & $T_{95 \%}=185-308^{b}$ & $M_{\mathrm{n}}=22,300-46,000 \mathrm{~g} \mathrm{~mol}^{-1}$ & Rostagno et al. [97] \\
\hline 11 & Vanillin & ${ }^{2}$ & $\begin{array}{l}\text { Poly (ether } \\
\text { benzoxazole) }\end{array}$ & - & $>400^{b}$ & - & Sun et al. [112] \\
\hline 12 & $\begin{array}{l}\text { Vanillin-based } \\
\text { monomers }\end{array}$ & $\begin{array}{l}\text { Phosphonite-mediated } \\
\text { multicomponent } \\
\text { polymerization }\end{array}$ & $\begin{array}{l}\text { Fluorescent } \\
\text { polymers }\end{array}$ & - & - & $\begin{array}{c}M_{\mathrm{n}}=3000-12,700 \mathrm{~g} \mathrm{~mol}^{-1} \\
Đ=1.8-2.3\end{array}$ & Kayser et al. [108] \\
\hline
\end{tabular}


Table 2. Cont.

\begin{tabular}{|c|c|c|c|c|c|c|c|}
\hline Entry & Monomers & $\begin{array}{l}\text { Polymerization } \\
\text { Method }\end{array}$ & Final Polymer & $\begin{array}{l}\text { Glass Transition } \\
\text { Temperature }\left({ }^{\circ} \mathrm{C}\right)\end{array}$ & Degradation Temperature $\left({ }^{\circ} \mathrm{C}\right)$ & Other Properties & Ref. \\
\hline 13 & Vanillyl alcohol & - & Polyurethane & 59 & $T_{5 \%}=178^{b}$ & $M_{w}=32,000 \mathrm{~g} \mathrm{~mol}^{-1}$ & Tachibana and Abe [113] \\
\hline 14 & Vanillin & - & $\begin{array}{l}\text { Polyurethane } \\
\text { (PU-3) }\end{array}$ & $80.4^{\mathrm{c}}$ & $T_{5 \%}=229^{b}$ & $M_{\mathrm{n}}=4000 \mathrm{~g} \mathrm{~mol}^{-1}$ & Zhao et al. [114] \\
\hline 15 & Vanillin & - & Cured epoxy resins & - & $T_{5 \%}=394^{b}$ & - & Shibata and Ohkita [115] \\
\hline 16 & Vanillin & $\begin{array}{l}\text { Phthalonitrile } \\
\text { functionalization }\end{array}$ & $\begin{array}{l}\text { Phthalonitrile } \\
\text { resins }\end{array}$ & $>500^{c}$ & $T_{5 \%}=477-482^{b}$ & - & Han et al. [116] \\
\hline 17 & Hydrovanilloin & $\begin{array}{l}\text { Electrochemical } \\
\text { dimerization }\end{array}$ & $\begin{array}{l}\text { Hydrovanilloin- } \\
\text { Diglycidyl Ether } \\
\text { Phenoxy Resin }\end{array}$ & 135 & $T=255^{d}$ & - & Amarasekara et al. [117] \\
\hline 18 & $\begin{array}{l}\text { Vanillin } \\
\text { methacrylate }\end{array}$ & $\begin{array}{l}\text { Free radical solution } \\
\text { homo-polymerization }\end{array}$ & $\begin{array}{l}\text { Vanillin-derived } \\
\text { polymer (PVMA) }\end{array}$ & - & - & $M_{\mathrm{n}}=17,900 \mathrm{~g} \mathrm{~mol}^{-1}$ & Zhao et al. [118] \\
\hline
\end{tabular}




\section{Summary and Outlook}

Lignin is an intriguing aromatic biopolymer. The release of more chemicals derived from lignin can expand available biorefinery feedstocks, thereby making economics of biorefineries and pulp and paper industries profitable. In this regard, this review gives an overview of processes that enable to deliver bio-based polymers from pre-isolated lignin or lignocellulose in good selectivities. As shown in this review, the applications of lignin to the manufacture of bio-based polymers demonstrate why lignin is regarded as a key renewable source in biorefineries. However, there are still challenges that need to be solved to be capable of the full implementation of lignin as renewable feedstock for bio-based polymers.

There are a large number of strategies to transform lignin into aromatic aldehydes such as syringaldehyde and vanillin. Many studies have recognized that re-condensation reactions occurring during processing lignocellulosic biomass and lignin conversion processes have pronounced effects on the product yields. Efforts to suppress the undesired reactions have been made. For instance, the introduction of formaldehyde to isolating lignin from lignocellulosic biomass achieved the yields at a near theoretical maximum [119]. Stabilization of reactive intermediate species during acidolysis of organosolv lignin was also reported [120-122]. Reductive catalytic fractionation led to high selectivities toward defined target products rather than obtaining a complex mixture of products [123].

The aerobic oxidation of lignin reported so far needs for high amounts of oxygen and alkali medium. However, most studies have still focused on increasing yields of target products, although reducing the oxygen and alkali consumption is clearly attention-worthy issue [124]. More efforts should be made to figure out how to lower the consumption of oxygen and alkali during the aromatic aldehyde production.

Most studies into the production of aromatic aldehydes from lignin that are currently available have laid emphasis on solving fundamental challenges of selective $\beta-\mathrm{O}-4$ bond cleavage in lignin. However, cleavage of other linkages in lignin needs to be more actively investigated to fully valorize all lignin components. Stable and reusable catalysts that are tolerant to impurities contained in lignin should be developed [125]. Upscaling of experiments on converting lignin into the monomers is also required as an effort to make the lignin valorization process more economically viable.

For the conversion of lignin into aromatic aldehyde monomers, it is difficult to make a direct comparison of the conversion processes because characteristics and properties of lignin substances (e.g., purity, solubility, molecular weight, and $\beta$-O-4 content) are different, dependent upon the methods of lignin isolation and processing developed by different research groups. Thus, standardization of reporting performance of the lignin conversion methods is required. Regarding the standardization, the lack of standard lignin samples that have reproducible quality is a serious challenge. It is also necessary to standardize existing techniques for analysis both of the structure of lignin and lignocellulose and of lignin-derived complicated product mixtures.

Considerable advancements have come with polymers made from lignin-derived aromatic aldehydes. Many research groups have used pure and well-defined lignin substrates available from commercial sources to synthesize bio-based polymers, particularly thermoplastics and thermosets with comparable properties to conventional materials. However, there is still a discrepancy between chemical compounds frequently obtained from depolymerization of lignin and monomers most frequently used for the production of bio-based polymers. Novel methods to make the actual monomers with high yields are needed, which can open up possibilities of synthesizing emerging bio-based polymers having desired properties.

Catalytic conversions of lignin typically result in mixtures of different aromatic compounds that are directly employed to synthesize bio-based polymers. This can allow to avoid additional purification or separation steps, if reproducibility associated with the kind of lignin feedstocks and the composition of the aromatic mixtures is clarified. Moreover, the lignin-derived bio-based polymers are not degradable in nature; hence, their biodegradability and toxicity in the environment need to be further investigated. 
In the past, the use of lignin as a starting material for the production of other chemicals was skeptical because the breakage of recalcitrant structure of lignin was a daunting task. Today, considerable advancements in research into biorefinery and catalysis make it possible the production of lignin-derived platform chemicals in acceptable yields. However, the full implementation of lignin as renewable feedstock for bio-based polymers still requires active collaborations across multiple disciplines and a constructive dialogue between people working in academia and industry. Constant efforts to develop lignin valorization processes will be essential for further innovation in biorefinery technologies.

Author Contributions: Conceptualization, J.L.; writing—original draft preparation, N.L., Y.T.K. and J.L.; writing-review and editing, N.L., Y.T.K. and J.L.; visualization, N.L. and Y.T.K.; supervision, J.L. All authors have read and agreed to the published version of the manuscript.

Funding: This work was supported by the National Research Foundation of Korea (NRF) grant funded by the Korean Government (Ministry of Science and ICT) (No. NRF-2020R1C1C1003225). This work was also supported by the KRICT project (SI2112-10) of the Korea Research Institute of Chemical Technology.

Institutional Review Board Statement: Not Applicable.

Informed Consent Statement: Not Applicable.

Data Availability Statement: Not Applicable.

Conflicts of Interest: The authors declare no conflict of interest.

\section{References}

1. De Bhowmick, G.; Sarmah, A.K.; Sen, R. Lignocellulosic biorefinery as a model for sustainable development of biofuels and value added products. Bioresour. Technol. 2018, 247, 1144-1154. [CrossRef] [PubMed]

2. Kwon, E.E.; Lee, T.; Ok, Y.S.; Tsang, D.C.W.; Park, C.; Lee, J. Effects of calcium carbonate on pyrolysis of sewage sludge. Energy 2018, 153, 726-731. [CrossRef]

3. Jung, J.-M.; Oh, J.-I.; Baek, K.; Lee, J.; Kwon, E.E. Biodiesel production from waste cooking oil using biochar derived from chicken manure as a porous media and catalyst. Energy Convers. Manag. 2018, 165, 628-633. [CrossRef]

4. Kim, S.; Kwon, E.E.; Kim, Y.T.; Jung, S.; Kim, H.J.; Huber, G.W.; Lee, J. Recent advances in hydrodeoxygenation of biomass-derived oxygenates over heterogeneous catalysts. Green Chem. 2019, 21, 3715-3743. [CrossRef]

5. Park, C.; Lee, J. Recent achievements in $\mathrm{CO}_{2}$-assisted and $\mathrm{CO}_{2}$-catalyzed biomass conversion reactions. Green Chem. 2020, 22, 2628-2642. [CrossRef]

6. Cagnon, B.; Py, X.; Guillot, A.; Stoeckli, F.; Chambat, G. Contributions of hemicellulose, cellulose and lignin to the mass and the porous properties of chars and steam activated carbons from various lignocellulosic precursors. Bioresour. Technol. 2009, 100, 292-298. [CrossRef]

7. Schutyser, W.; Renders, T.; Van den Bosch, S.; Koelewijn, S.F.; Beckham, G.T.; Sels, B.F. Chemicals from lignin: An interplay of lignocellulose fractionation, depolymerisation, and upgrading. Chem. Soc. Rev. 2018, 47, 852-908. [CrossRef]

8. Sun, Z.; Fridrich, B.; de Santi, A.; Elangovan, S.; Barta, K. Bright side of lignin depolymerization: Toward new platform chemicals. Chem. Rev. 2018, 118, 614-678. [CrossRef]

9. Rinaldi, R.; Jastrzebski, R.; Clough, M.T.; Ralph, J.; Kennema, M.; Bruijnincx, P.C.A.; Weckhuysen, B.M. Paving the way for lignin valorisation: Recent advances in bioengineering, biorefining and catalysis. Angew. Chem. Int. Ed. 2016, 55, 8164-8215. [CrossRef]

10. Gillet, S.; Aguedo, M.; Petitjean, L.; Morais, A.R.C.; da Costa Lopes, A.M.; Łukasik, R.M.; Anastas, P.T. Lignin transformations for high value applications: Towards targeted modifications using green chemistry. Green Chem. 2017, 19, 4200-4233. [CrossRef]

11. Shuai, L.; Saha, B. Towards high-yield lignin monomer production. Green Chem. 2017, 19, 3752-3758. [CrossRef]

12. Renders, T.; Van den Bosch, S.; Koelewijn, S.F.; Schutyser, W.; Sels, B.F. Lignin-first biomass fractionation: The advent of active stabilisation strategies. Energy Environ. Sci. 2017, 10, 1551-1557. [CrossRef]

13. Gierer, J. Chemistry of delignification. Wood Sci. Technol. 1985, 19, 289-312. [CrossRef]

14. Sturgeon, M.R.; Kim, S.; Lawrence, K.; Paton, R.S.; Chmely, S.C.; Nimlos, M.; Foust, T.D.; Beckham, G.T. A mechanistic investigation of acid-catalyzed cleavage of aryl-ether linkages: Implications for lignin depolymerization in acidic environments. ACS Sustain. Chem. Eng. 2014, 2, 472-485. [CrossRef]

15. Pu, Y.; Hu, F.; Huang, F.; Ragauskas, A.J. Lignin structural alterations in thermochemical pretreatments with limited delignification. Bioenerg. Res. 2015, 8, 992-1003. [CrossRef]

16. Liu, S.; Bai, L.; van Muyden, A.P.; Huang, Z.; Cui, X.; Fei, Z.; Li, X.; Hu, X.; Dyson, P.J. Oxidative cleavage of $\beta-O-4$ bonds in lignin model compounds with a single-atom Co catalyst. Green Chem. 2019, 21, 1974-1981. [CrossRef]

17. Lora, J. Industrial commercial lignins: Sources, properties and applications. In Monomers, Polymers and Composites from Renewable Resources; Belgacem, M.N., Gandini, A., Eds.; Elsevier: Amsterdam, The Netherlands, 2008; pp. 225-241. [CrossRef] 
18. Ragauskas, A.J.; Beckham, G.T.; Biddy, M.J.; Chandra, R.; Chen, F.; Davis, M.F.; Davison, B.H.; Dixon, R.A.; Gilna, P.; Keller, M.; et al. Lignin valorization: Improving lignin processing in the biorefinery. Science 2014, 344, 1246843. [CrossRef]

19. Davis, R.; Tao, L.; Tan, E.; Biddy, M.; Beckham, G.; Scarlata, C.; Jacobson, J.; Cafferty, K.; Ross, J.; Lukas, J. Process Design and Economics for the Conversion of Lignocellulosic Biomass to Hydrocarbons: Dilute-Acid and Enzymatic Deconstruction of Biomass to Sugars and Biological Conversion of Sugars to Hydrocarbons; Report NREL/TP-5100-60223; National Renewable Energy Laboratory: Golden, CO, USA, 2013.

20. Zhu, Y.; Romain, C.; Williams, C.K. Sustainable polymers from renewable resources. Nature 2016, 540, 354-362. [CrossRef]

21. Delidovich, I.; Hausoul, P.J.C.; Deng, L.; Pfützenreuter, R.; Rose, M.; Palkovits, R. Alternative monomers based on lignocellulose and their use for polymer production. Chem. Rev. 2016, 116, 1540-1599. [CrossRef]

22. Cheng, C.; Wang, J.; Shen, D.; Xue, J.; Guan, S.; Gu, S.; Luo, K.H. Catalytic oxidation of lignin in solvent systems for production of renewable chemicals: A review. Polymers 2017, 9, 240. [CrossRef]

23. Rodrigues Pinto, P.C.; Borges da Silva, E.A.; Rodrigues, A.E. Lignin as source of fine chemicals: Vanillin and syringaldehyde. In Biomass Conversion: The Interface of Biotechnology, Chemistry and Materials Science; Baskar, C., Baskar, S., Dhillon, R.S., Eds.; Springer: Berlin/Heidelberg, Germany, 2012; pp. 381-420. [CrossRef]

24. Fache, M.; Boutevin, B.; Caillol, S. Vanillin production from lignin and its use as a renewable chemical. ACS Sustain. Chem. Eng. 2016, 4, 35-46. [CrossRef]

25. Fargues, C.; Mathias, Á.; Rodrigues, A. Kinetics of vanillin production from Kraft lignin oxidation. Ind. Eng. Chem. Res. 1996, 35, 28-36. [CrossRef]

26. Villar, J.C.; Caperos, A.; García-Ochoa, F. Oxidation of hardwood Kraft-lignin to phenolic derivatives with oxygen as oxidant. Wood Sci. Technol. 2001, 35, 245-255. [CrossRef]

27. Araújo, J.D.P.; Grande, C.A.; Rodrigues, A.E. Vanillin production from lignin oxidation in a batch reactor. Chem. Eng. Res. Des. 2010, 88, 1024-1032. [CrossRef]

28. Rodrigues Pinto, P.C.; Borges da Silva, E.A.; Rodrigues, A.E. Insights into oxidative conversion of lignin to high-added-value phenolic aldehydes. Ind. Eng. Chem. Res. 2011, 50, 741-748. [CrossRef]

29. Pinto, P.C.R.; Costa, C.E.; Rodrigues, A.E. Oxidation of lignin from Eucalyptus globulus pulping liquors to produce syringaldehyde and vanillin. Ind. Eng. Chem. Res. 2013, 52, 4421-4428. [CrossRef]

30. Tarabanko, V.E.; Fomova, N.A.; Kuznetsov, B.N.; Ivanchenko, N.M.; Kudryashev, A.V. On the mechanism of vanillin formation in the catalytic oxidation of lignin with oxygen. React. Kinet. Catal. Lett. 1995, 55, 161-170. [CrossRef]

31. Bjørsvik, H.-R.; Minisci, F. Fine chemicals from lignosulfonates. 1. Synthesis of vanillin by oxidation of lignosulfonates. Org. Process Res. Dev. 1999, 3, 330-340. [CrossRef]

32. Santos, S.G.; Marques, A.P.; Lima, D.L.D.; Evtuguin, D.V.; Esteves, V.I. Kinetics of Eucalypt lignosulfonate oxidation to aromatic aldehydes by oxygen in alkaline medium. Ind. Eng. Chem. Res. 2011, 50, 291-298. [CrossRef]

33. Pacek, A.W.; Ding, P.; Garrett, M.; Sheldrake, G.; Nienow, A.W. Catalytic conversion of sodium lignosulfonate to vanillin: Engineering aspects. Part 1. Effects of processing conditions on vanillin yield and selectivity. Ind. Eng. Chem. Res. 2013, 52, 8361-8372. [CrossRef]

34. Mathias, A.L.; Rodrigues, A.E. Production of vanillin by oxidation of pine Kraft lignins with oxygen. Holzforschung 1995, 49, 273-278. [CrossRef]

35. Tarabanko, V.E.; Petukhov, D.V. Study of mechanism and improvement of the process of oxidative cleavage of lignins into the aromatic aldehydes. Chem. Sustain. Dev. 2003, 11, 655-667.

36. Tarabanko, V.E.; Petukhov, D.V.; Selyutin, G.E. New mechanism for the catalytic oxidation of lignin to vanillin. Kinet. Catal. 2004, 45, 569-577. [CrossRef]

37. Hosoya, T.; Yamamoto, K.; Miyafuji, H.; Yamada, T. Selective production of bio-based aromatics by aerobic oxidation of native soft wood lignin in tetrabutylammonium hydroxide. RSC Adv. 2020, 10, 19199-19210. [CrossRef]

38. Wu, G.; Heitz, M. Catalytic mechanism of $\mathrm{Cu}^{2+}$ and $\mathrm{Fe}^{3+}$ in alkaline $\mathrm{O}_{2}$ oxidation of lignin. J. Wood Chem. Technol. 1995, 15, 189-202. [CrossRef]

39. Araújo, J.D.P.; Grande, C.A.; Rodrigues, A.E. Structured packed bubble column reactor for continuous production of vanillin from Kraft lignin oxidation. Catal. Today 2009, 147, S330-S335. [CrossRef]

40. Constant, S.; Wienk, H.L.J.; Frissen, A.E.; Peinder, P.d.; Boelens, R.; Van Es, D.S.; Grisel, R.J.H.; Weckhuysen, B.M.; Huijgen, W.J.J.; Gosselink, R.J.A.; et al. New insights into the structure and composition of technical lignins: A comparative characterisation study. Green Chem. 2016, 18, 2651-2665. [CrossRef]

41. Ekielski, A.; Mishra, P.K. Lignin for bioeconomy: The present and future role of technical lignin. Int. J. Mol. Sci. 2021, 22, 63. [CrossRef]

42. Schutyser, W.; Kruger, J.S.; Robinson, A.M.; Katahira, R.; Brandner, D.G.; Cleveland, N.S.; Mittal, A.; Peterson, D.J.; Meilan, R.; Román-Leshkov, Y.; et al. Revisiting alkaline aerobic lignin oxidation. Green Chem. 2018, 20, 3828-3844. [CrossRef]

43. Silva, E.A.B.D.; Zabkova, M.; Araújo, J.D.; Cateto, C.A.; Barreiro, M.F.; Belgacem, M.N.; Rodrigues, A.E. An integrated process to produce vanillin and lignin-based polyurethanes from Kraft lignin. Chem. Eng. Res. Des. 2009, 87, 1276-1292. [CrossRef]

44. Mota, M.I.F.; Rodrigues Pinto, P.C.; Loureiro, J.M.; Rodrigues, A.E. Recovery of vanillin and syringaldehyde from lignin oxidation: A review of separation and purification processes. Sep. Purif. Rev. 2016, 45, 227-259. [CrossRef] 
45. Mabrouk, A.; Erdocia, X.; Alriols, M.G.; Labidi, J. Economic analysis of a biorefinery process for catechol production from lignin. J. Clean. Prod. 2018, 198, 133-142. [CrossRef]

46. Wang, Y.; Sun, S.; Li, F.; Cao, X.; Sun, R. Production of vanillin from lignin: The relationship between $\beta$-O-4 linkages and vanillin yield. Ind. Crops Prod. 2018, 116, 116-121. [CrossRef]

47. Mohamad Ibrahim, M.N.; Nadiah, M.Y.N.; Norliyana, M.S.; Sipaut, C.S.; Shuib, S. Separation of vanillin from oil palm empty fruit bunch lignin. Clean (Weinh.) 2008, 36, 287-291. [CrossRef]

48. Taraban'ko, V.E.; Koropatchinskaya, N.V.; Kudryashev, A.V.; Kuznetsov, B.N. Influence of lignin origin on the efficiency of the catalytic oxidation of lignin into vanillin and syringaldehyde. Russ. Chem. Bull. 1995, 44, 367-371. [CrossRef]

49. Wong, Z.; Chen, K.; Li, J. Formation of vanillin and syringaldehyde in an oxygen delignification process. Bioresources 2010, 5 , 1509-1516.

50. Zhang, J.; Deng, H.; Lin, L. Wet aerobic oxidation of lignin into aromatic aldehydes catalysed by a perovskite-type oxide: $\mathrm{LaFe}_{1-\mathrm{x}} \mathrm{Cu}_{\mathrm{x}} \mathrm{O}_{3}(\mathrm{x}=0,0.1,0.2)$. Molecules 2009, 14, 2747-2757. [CrossRef]

51. Gomes, E.D.; Rodrigues, A.E. Lignin biorefinery: Separation of vanillin, vanillic acid and acetovanillone by adsorption. Sep. Purif. Technol. 2019, 216, 92-101. [CrossRef]

52. Li, Y.-X.; Zhu, J.-P.; Zhang, Z.-J.; Qu, Y.-S. Preparation of syringaldehyde from lignin by catalytic oxidation of perovskite-type oxides. ACS Omega 2020, 5, 2107-2113. [CrossRef]

53. Jeon, W.; Choi, I.-H.; Park, J.-Y.; Lee, J.-S.; Hwang, K.-R. Alkaline wet oxidation of lignin over Cu-Mn mixed oxide catalysts for production of vanillin. Catal. Today 2020, 352, 95-103. [CrossRef]

54. Maeda, M.; Hosoya, T.; Yoshioka, K.; Miyafuji, H.; Ohno, H.; Yamada, T. Vanillin production from native softwood lignin in the presence of tetrabutylammonium ion. J. Wood Sci. 2018, 64, 810-815. [CrossRef]

55. Gomes, E.D.; Rodrigues, A.E. Recovery of vanillin from kraft lignin depolymerization with water as desorption eluent. Sep. Purif. Technol. 2020, 239, 116551. [CrossRef]

56. Gitaari, N.; Benard, K.; Gichuki, J.; Kareru, P. Synthesis of vanillin from lignin. Chem. Sci. Int. J. 2019, 27, 1-5. [CrossRef]

57. Zhu, Y.; Liao, Y.; Lv, W.; Liu, J.; Song, X.; Chen, L.; Wang, C.; Sels, B.F.; Ma, L. Complementing vanillin and cellulose production by oxidation of lignocellulose with stirring control. ACS Sustain. Chem. Eng. 2020, 8, 2361-2374. [CrossRef]

58. Zhang, R.; Maltari, R.; Guo, M.; Kontro, J.; Eronen, A.; Repo, T. Facile synthesis of vanillin from fractionated Kraft lignin. Ind. Crops Prod. 2020, 145, 112095. [CrossRef]

59. Yan, K.; Zhang, Y.; Tu, M.; Sun, Y. Electrocatalytic valorization of organosolv lignin utilizing a nickel-based electrocatalyst. Energy Fuels 2020, 34, 12703-12709. [CrossRef]

60. Liu, S.; Das, L.; Blauch, D.N.; Veronee, C.; Dou, C.; Gladden, J.; Sun, N.; Socha, A.M. Statistical design of experiments for production and purification of vanillin and aminophenols from commercial lignin. Green Chem. 2020, 22, 3917-3926. [CrossRef]

61. Ninomiya, K.; Ochiai, K.; Eguchi, M.; Kuroda, K.; Tsuge, Y.; Ogino, C.; Taima, T.; Takahashi, K. Oxidative depolymerization potential of biorefinery lignin obtained by ionic liquid pretreatment and subsequent enzymatic saccharification of eucalyptus. Ind. Crops Prod. 2018, 111, 457-461. [CrossRef]

62. Westwood, N.J.; Panovic, I.; Lancefield, C.S. Chemical modification of lignin for renewable polymers or chemicals. In Production of Biofuels and Chemicals from Lignin; Fang, Z., Smith, J.R.L., Eds.; Springer: Singapore, 2016; pp. 183-216. [CrossRef]

63. Upton, B.M.; Kasko, A.M. Strategies for the conversion of lignin to high-value polymeric materials: Review and perspective. Chem. Rev. 2016, 116, 2275-2306. [CrossRef]

64. Sen, S.; Patil, S.; Argyropoulos, D.S. Thermal properties of lignin in copolymers, blends, and composites: A review. Green Chem. 2015, 17, 4862-4887. [CrossRef]

65. Faruk, O.; Sain, M. Lignin in Polymer Composites; Elsevier: Amsterdam, The Netherlands, 2016.

66. Llevot, A.; Grau, E.; Carlotti, S.; Grelier, S.; Cramail, H. From lignin-derived aromatic compounds to novel biobased polymers. Macromol. Rapid Commun. 2016, 37, 9-28. [CrossRef] [PubMed]

67. Li, C.; Zhao, X.; Wang, A.; Huber, G.W.; Zhang, T. Catalytic transformation of lignin for the production of chemicals and fuels. Chem. Rev. 2015, 115, 11559-11624. [CrossRef] [PubMed]

68. Fache, M.; Boutevin, B.; Caillol, S. Vanillin, a key-intermediate of biobased polymers. Eur. Polym. J. 2015, 68, 488-502. [CrossRef]

69. Fache, M.; Darroman, E.; Besse, V.; Auvergne, R.; Caillol, S.; Boutevin, B. Vanillin, a promising biobased building-block for monomer synthesis. Green Chem. 2014, 16, 1987-1998. [CrossRef]

70. Fache, M.; Viola, A.; Auvergne, R.; Boutevin, B.; Caillol, S. Biobased epoxy thermosets from vanillin-derived oligomers. Eur. Polym. J. 2015, 68, 526-535. [CrossRef]

71. Fache, M.; Auvergne, R.; Boutevin, B.; Caillol, S. New vanillin-derived diepoxy monomers for the synthesis of biobased thermosets. Eur. Polym. J. 2015, 67, 527-538. [CrossRef]

72. Harvey, B.G.; Guenthner, A.J.; Meylemans, H.A.; Haines, S.R.L.; Lamison, K.R.; Groshens, T.J.; Cambrea, L.R.; Davis, M.C.; Lai, W.W. Renewable thermosetting resins and thermoplastics from vanillin. Green Chem. 2015, 17, 1249-1258. [CrossRef]

73. Stanzione Iii, J.F.; Sadler, J.M.; La Scala, J.J.; Reno, K.H.; Wool, R.P. Vanillin-based resin for use in composite applications. Green Chem. 2012, 14, 2346-2352. [CrossRef]

74. Mirzakhanian, Z.; Faghihi, K.; Geravi, H.A.; Mahdieh, M. Semi-aromatic polyimide/Ag nanocomposite derived from vanillin. J. Appl. Polym. Sci. 2016, 133, 44001. [CrossRef] 
75. Chauhan, N.P.S.; Kataria, P.; Chaudhary, J.; Ameta, S.C. Synthesis, Characterization, and Thermal Studies of Terpolymers Derived from Vanillin, Furfural, and Halo-Substituted Acetophenones. Int. J. Polym. Mater. Polym. Biomater. 2012, 61, 57-71. [CrossRef]

76. Chauhan, N.P.S. Preparation and characterization of bio-based terpolymer derived from vanillin oxime, formaldehyde, and p-hydroxyacetophenone. Des. Monomers Polym. 2014, 17, 176-185. [CrossRef]

77. Sini, N.K.; Bijwe, J.; Varma, I.K. Renewable benzoxazine monomer from Vanillin: Synthesis, characterization, and studies on curing behavior. J. Polym. Sci. Part A Polym. Chem. 2014, 52, 7-11. [CrossRef]

78. Nishimura, R.T.; Giammanco, C.H.; Vosburg, D.A. Green, enzymatic syntheses of divanillin and diapocynin for the organic, biochemistry, or advanced general chemistry laboratory. J. Chem. Educ. 2010, 87, 526-527. [CrossRef]

79. Llevot, A.; Grau, E.; Carlotti, S.; Grelier, S.; Cramail, H. Renewable (semi)aromatic polyesters from symmetrical vanillin-based dimers. Polym. Chem. 2015, 6, 6058-6066. [CrossRef]

80. Llevot, A.; Grau, E.; Carlotti, S.; Grelier, S.; Cramail, H. Selective laccase-catalyzed dimerization of phenolic compounds derived from lignin: Towards original symmetrical bio-based (bis) aromatic monomers. J. Mol. Catal. B Enzym. 2016, 125, 34-41. [CrossRef]

81. Savonnet, E.; Grau, E.; Grelier, S.; Defoort, B.; Cramail, H. Divanillin-based epoxy precursors as DGEBA substitutes for biobased epoxy thermosets. ACS Sustain. Chem. Eng. 2018, 6, 11008-11017. [CrossRef]

82. Yamamoto, H.; Hoshino, T.; Uchiyama, T. Convenient preparation and quantification of 5,5'-diferulic acid. Biosci. Biotechnol. Biochem. 1999, 63, 390-394. [CrossRef]

83. Kelly, D.R.; Baker, S.C.; King, D.S.; de Silva, D.S.; Lord, G.; Taylor, J.P. Studies of nitrile oxide cycloadditions, and the phenolic oxidative coupling of vanillin aldoxime by Geobacillus sp. DDS012 from Italian rye grass silage. Org. Biomol. Chem. 2008, 6, 787-796. [CrossRef]

84. Delomenède, M.; Bedos-Belval, F.; Duran, H.; Vindis, C.; Baltas, M.; Nègre-Salvayre, A. Development of novel antiatherogenic biaryls: Design, synthesis, and reactivity. J. Med. Chem. 2008, 51, 3171-3181. [CrossRef]

85. Fang, Z.; Nikafshar, S.; Hegg, E.L.; Nejad, M. Biobased divanillin as a precursor for formulating biobased epoxy resin. ACS Sustain. Chem. Eng. 2020, 8, 9095-9103. [CrossRef]

86. Amarasekara, A.S.; Wiredu, B.; Razzaq, A. Vanillin based polymers: I. An electrochemical route to polyvanillin. Green Chem. 2012, 14, 2395-2397. [CrossRef]

87. Maiorana, A.; Reano, A.F.; Centore, R.; Grimaldi, M.; Balaguer, P.; Allais, F.; Gross, R.A. Structure property relationships of biobased n-alkyl bisferulate epoxy resins. Green Chem. 2016, 18, 4961-4973. [CrossRef]

88. Amarasekara, A.S.; Razzaq, A. Vanillin-based polymers-Part II: Synthesis of Schiff base polymers of divanillin and their chelation with metal ions. ISRN Polym. Sci. 2012, 2012, 532171. [CrossRef]

89. Fache, M.; Boutevin, B.; Caillol, S. Epoxy thermosets from model mixtures of the lignin-to-vanillin process. Green Chem. 2016, 18, 712-725. [CrossRef]

90. Zhao, S.; Abu-Omar, M.M. Recyclable and malleable epoxy thermoset bearing aromatic imine bonds. Macromolecules 2018, 51, 9816-9824. [CrossRef]

91. Forsythe, W.G.; Garrett, M.D.; Hardacre, C.; Nieuwenhuyzen, M.; Sheldrake, G.N. An efficient and flexible synthesis of model lignin oligomers. Green Chem. 2013, 15, 3031-3038. [CrossRef]

92. Llevot, A.; Grau, E.; Carlotti, S.; Grelier, S.; Cramail, H. ADMET polymerization of bio-based biphenyl compounds. Polym. Chem. 2015, 6, 7693-7700. [CrossRef]

93. Gang, H.; Lee, D.; Choi, K.-Y.; Kim, H.-N.; Ryu, H.; Lee, D.-S.; Kim, B.-G. Development of high performance polyurethane elastomers using vanillin-based green polyol chain extender originating from lignocellulosic biomass. ACS Sustain. Chem. Eng. 2017, 5, 4582-4588. [CrossRef]

94. Wang, S.; Ma, S.; Xu, C.; Liu, Y.; Dai, J.; Wang, Z.; Liu, X.; Chen, J.; Shen, X.; Wei, J.; et al. Vanillin-derived high-performance flame retardant epoxy resins: Facile synthesis and properties. Macromolecules 2017, 50, 1892-1901. [CrossRef]

95. Hernandez, E.D.; Bassett, A.W.; Sadler, J.M.; La Scala, J.J.; Stanzione, J.F. Synthesis and characterization of bio-based epoxy resins derived from vanillyl alcohol. ACS Sustain. Chem. Eng. 2016, 4, 4328-4339. [CrossRef]

96. An, E.S.; Cho, D.H.; Choi, J.W.; Kim, Y.H.; Song, B.K. Peroxidase-catalyzed copolymerization of syringaldehyde and bisphenol A. Enzyme Microb. Technol. 2010, 46, 287-291. [CrossRef]

97. Rostagno, M.; Shen, S.; Ghiviriga, I.; Miller, S.A. Sustainable polyvinyl acetals from bioaromatic aldehydes. Polym. Chem. 2017, 8, 5049-5059. [CrossRef]

98. Kwon, J.; Kim, J.; Park, S.; Khang, G.; Kang, P.M.; Lee, D. Inflammation-responsive antioxidant nanoparticles based on a polymeric prodrug of vanillin. Biomacromolecules 2013, 14, 1618-1626. [CrossRef] [PubMed]

99. Liu, H.; Lepoittevin, B.; Roddier, C.; Guerineau, V.; Bech, L.; Herry, J.-M.; Bellon-Fontaine, M.-N.; Roger, P. Facile synthesis and promising antibacterial properties of a new guaiacol-based polymer. Polymer 2011, 52, 1908-1916. [CrossRef]

100. Zhou, J.; Zhang, H.; Deng, J.; Wu, Y. High glass-transition temperature acrylate polymers derived from biomasses, syringaldehyde, and vanillin. Macromol. Chem. Phys. 2016, 217, 2402-2408. [CrossRef]

101. Kakuchi, R.; Yoshida, S.; Sasaki, T.; Kanoh, S.; Maeda, K. Multi-component post-polymerization modification reactions of polymers featuring lignin-model compounds. Polym. Chem. 2018, 9, 2109-2115. [CrossRef]

102. Zhang, H.; Yong, X.; Zhou, J.; Deng, J.; Wu, Y. Biomass vanillin-derived polymeric microspheres containing functional aldehyde groups: Preparation, characterization, and application as adsorbent. ACS Appl. Mater. Interfaces 2016, 8, 2753-2763. [CrossRef] 
103. Zhang, H.; Deng, J.; Wu, Y. Biobased magnetic microspheres containing aldehyde groups: Constructed by vanillin-derived polymethacrylate $/ \mathrm{Fe}_{3} \mathrm{O}_{4}$ and recycled in adsorbing amine. ACS Sustain. Chem. Eng. 2017, 5, 658-666. [CrossRef]

104. Ma, S.; Li, T.; Liu, X.; Zhu, J. Research progress on bio-based thermosetting resins. Polym. Int. 2016, 65, 164-173. [CrossRef]

105. Ratna, D. Handbook of Thermoset Resins; iSmithers: Shawbury, UK, 2009.

106. Auvergne, R.; Caillol, S.; David, G.; Boutevin, B.; Pascault, J.-P. Biobased thermosetting epoxy: Present and future. Chem. Rev. 2014, 114, 1082-1115. [CrossRef]

107. Zhao, S.; Abu-Omar, M.M. Renewable thermoplastics based on lignin-derived polyphenols. Macromolecules 2017, 50, 3573-3581. [CrossRef]

108. Kayser, L.V.; Hartigan, E.M.; Arndtsen, B.A. Multicomponent coupling approach to cross-conjugated polymers from vanillinbased monomers. ACS Sustain. Chem. Eng. 2016, 4, 6263-6267. [CrossRef]

109. Holmberg, A.L.; Nguyen, N.A.; Karavolias, M.G.; Reno, K.H.; Wool, R.P.; Epps, T.H. Softwood lignin-based methacrylate polymers with tunable thermal and viscoelastic properties. Macromolecules 2016, 49, 1286-1295. [CrossRef]

110. Holmberg, A.L.; Reno, K.H.; Nguyen, N.A.; Wool, R.P.; Epps, T.H. Syringyl methacrylate, a hardwood lignin-based monomer for high- $T_{\mathrm{g}}$ polymeric materials. ACS Macro Lett. 2016, 5, 574-578. [CrossRef] [PubMed]

111. Sini, N.K.; Bijwe, J.; Varma, I.K. Thermal behaviour of bis-benzoxazines derived from renewable feed stock 'vanillin'. Polym. Degrad. Stab. 2014, 109, 270-277. [CrossRef]

112. Sun, H.; Young, Y.D.; Kanehashi, S.; Tsuchiya, K.; Ogino, K.; Sim, J.-H. Synthesis and characterization of biobased poly (ether benzoxazole) derived from vanillin. J. Fiber Sci. Technol. 2016, 72, 89-95. [CrossRef]

113. Tachibana, K.; Abe, H. Studies on thermo-mechanical and thermal degradation properties of bio-based polyurethanes synthesized from vanillin-derived diol and lysine diisocyanate. Polym. Degrad. Stab. 2019, 167, 283-291. [CrossRef]

114. Zhao, C.; Huang, C.; Chen, Q.; Ingram, I.D.V.; Zeng, X.; Ren, T.; Xie, H. Sustainable aromatic aliphatic polyesters and polyurethanes prepared from vanillin-derived diols via green catalysis. Polymers 2020, 12, 586. [CrossRef]

115. Shibata, M.; Ohkita, T. Fully biobased epoxy resin systems composed of a vanillin-derived epoxy resin and renewable phenolic hardeners. Eur. Polym. J. 2017, 92, 165-173. [CrossRef]

116. Han, Y.; Tang, D.-H.; Wang, G.-X.; Sun, Y.-N.; Guo, Y.; Zhou, H.; Qiu, W.-F.; Zhao, T. Phthalonitrile resins derived from vanillin: Synthesis, curing behavior, and thermal properties. Chin. J. Polym. Sci. 2020, 38, 72-83. [CrossRef]

117. Amarasekara, A.S.; Garcia-Obergon, R.; Thompson, A.K. Vanillin-based polymers: IV. Hydrovanilloin epoxy resins. J. Appl. Polym. Sci. 2019, 136, 47000. [CrossRef]

118. Zhao, R.; Yong, X.; Pan, M.; Deng, J.; Pan, K. Aldehyde-containing nanofibers electrospun from biomass vanillin-derived polymer and their application as adsorbent. Sep. Purif. Technol. 2020, 246, 116916. [CrossRef]

119. Shuai, L.; Amiri, M.T.; Questell-Santiago, Y.M.; Héroguel, F.; Li, Y.; Kim, H.; Meilan, R.; Chapple, C.; Ralph, J.; Luterbacher, J.S. Formaldehyde stabilization facilitates lignin monomer production during biomass depolymerization. Science 2016, 354, 329-333. [CrossRef] [PubMed]

120. Deuss, P.J.; Scott, M.; Tran, F.; Westwood, N.J.; De Vries, J.G.; Barta, K. Aromatic monomers by in situ conversion of reactive intermediates in the acid-catalyzed depolymerization of lignin. J. Am. Chem. Soc. 2015, 137, 7456-7467. [CrossRef] [PubMed]

121. Lahive, C.W.; Deuss, P.J.; Lancefield, C.S.; Sun, Z.; Cordes, D.B.; Young, C.M.; Tran, F.; Slawin, A.M.Z.; De Vries, J.G.; Kamer, P.C.J.; et al. Advanced model compounds for understanding acid-catalyzed lignin depolymerization: Identification of renewable aromatics and a lignin-derived solvent. J. Am. Chem. Soc. 2016, 138, 8900-8911. [CrossRef]

122. Deuss, P.J.; Lancefield, C.S.; Narani, A.; De Vries, J.G.; Westwood, N.J.; Barta, K. Phenolic acetals from lignins of varying compositions via iron(iii) triflate catalysed depolymerisation. Green Chem. 2017, 19, 2774-2782. [CrossRef]

123. Galkin, M.V.; Samec, J.S.M. Lignin valorization through catalytic lignocellulose fractionation: A fundamental platform for the future biorefinery. ChemSusChem 2016, 9, 1544-1558. [CrossRef]

124. Tarabanko, V.E.; Tarabanko, N. Catalytic oxidation of lignins into the aromatic aldehydes: General process trends and development prospects. Int. J. Mol. Sci. 2017, 18, 2421. [CrossRef]

125. Kim, S.; Tsang, Y.F.; Kwon, E.E.; Lin, K.-Y.A.; Lee, J. Recently developed methods to enhance stability of heterogeneous catalysts for conversion of biomass-derived feedstocks. Korean J. Chem. Eng. 2019, 36, 1-11. [CrossRef] 